\title{
Efficacy of Freeze-dried Inactivated Rift Valley Fever Vaccine
}

\author{
Atwa, M.H ${ }^{1}$, Maha Raafat Abd El-Fadeel ${ }^{1}$, Heba A. Khafagy ${ }^{2 *}$, Alaa A.El-Kholy ${ }^{1}$, Ebtsam \\ E.Z.Kotb ${ }^{3}$, Marwa, F.Mahmoud ${ }^{3}$ \\ ${ }^{\mathbf{1}}$ Veterinary Serum and Vaccine Research Institute (VSVRI), Abbasia, Cairo, Egypt. \\ ${ }^{2}$ Central Laboratory for Evaluation of Veterinary Biologics (CLEVB), ), Abbasia, Cairo, Egypt. \\ ${ }^{3}$ Animal Reproduction Research Institute (ARRI), Haram, Giza, Egypt. \\ *Corresponding Author E-Mail: dr.hebakhafgy @ gmail.com; ORCID iD: https://orcid.org/0000-0003-4548-1824
}

\begin{abstract}
Rift Valley Fever (RVF) is an acute infectious zoonotic arthropod-born viral disease, affecting many species of animals and it causes great economic losses in animal wealth and has a zoonotic implication. Eradication of mosquito and vaccination is an important and best method for preventing and controlling the disease. This study was applied for the preparation and evaluation of Rift Valley Fever inactivated vaccine in a lyophilized form that is reconstituted at the time of inoculation using saponin that acts as an adjuvant. The prepared vaccine was proved to be sterile and safe. $\mathrm{ED}_{50}$ Potency test of the prepared vaccine in mice gave $0.0010 \mathrm{ED}_{50} / \mathrm{ML}$ (permissible limit less than $0.02 / \mathrm{ml}$ ). Sheep were vaccinated with $1 \mathrm{ml} \mathrm{S} \backslash \mathrm{C}$ of the prepared lyophilized inactivated RVF vaccine and another group was vaccinated $\mathrm{S} \mid \mathrm{C}$ with $1 \mathrm{ml}$ of Aluminum hydroxide inactivated RVF vaccine. The immune response of different vaccinated sheep groups was evaluated using SNT and ELISA. The Prepared lyophilized inactivated RVF vaccine gave protective NI at the second-week post-vaccination (2.1 and $0.286 \mathrm{OD})$ , then reach to peak at the $4^{\text {th }}$ week (3.28 and 0.343OD) then began to decline till ten months (1.8 and 0.241 OD), while the Aluminum hydroxide inactivated RVF vaccine gave protective NI at the second-week postvaccination $(1.7$ and $0.277 \mathrm{OD})$ then reach to its NI peak at the $4^{\text {th }}$ week (3.13 and $0.312 \mathrm{OD})$ then began to decline till ten months $(1.73$ and 0.228 OD). From the obtained results, it was found that the prepared lyophilized inactivated RVF vaccine was safe, potent and gave approximately similar immune response as aluminum hydroxide inactivated RVF vaccine but it is better as it reduces time and effort consuming during vaccine production.
\end{abstract}

Keywords: ELISA, NI, RVF, Saponin, SNT.

\section{INTRODUCTION}

Rift Valley fever (RVF) is an acute viral anthropoid zoonotic disease (Ndeye et al., 2015). It is caused by the Rift Valley Fever virus which a member of Phlebovirus of the Bunyaviridae, single-stranded RNA virus (Samia, 2011). It is transmitted by mosquito. The disease mainly affects sheep, goats, cattle, camels, buffaloes, and humans also cause fever, salivation, weakness, fetid diarrhea, decreased milk production with explosive abortions in pregnant animals (FAO, 2003). Finally, it causes a headache, conjunctivitis with ocular complications in the human CDC (2015). RVF outbreaks were associated with mosquito spreading (Nguku et al., 2006).

\section{Original Article: \\ DOI:HTTPS://DX.DOI.ORG/10.21 JJAVS.2020.85571}

Received:13 Feb., 2020.

Accepted : 19 March, 2020

Published in April, 2020.

This is an open access article under the term of the Creative Commons Attribution 4.0 (CCBY) International License . To view a copy of this license, visit http://creativecommons.org/licens es/by/4.0/

J. Appl. Vet. Sci., 5(2 ): 33- 39 .

The disease was first reported among livestock in Kenya around 1915, but the virus was not isolated until 1931 (CDC, 2007). It was introduced to Egypt through the importation of infected ruminants and camels from Sudan (Sellers et al., 1982) and reappeared in 1993 in Egypt (El-Gabery et al., 1994). It occurred in Egypt at Belbes and Zagazig Governorate. The virus has been isolated and designated (Imam et al., 1979). The best tool for protecting the animal population and indirectly humane being is the vector control and vaccination (Abdel Ghaffar $\boldsymbol{e t}$ al., 1979). There are two types of RVF vaccine live attenuated smith burn RVF vaccine and inactivated RVF vaccine (Faburay et al., 2017), but using it is limited due to teratogenic and aborteogenic effect (Kathryn et al., 1991). 


\section{Efficacy Of Freeze-Dried Inactivated ......}

In Egypt, the inactivated RVF vaccine is used with booster dose must be given to induce suitable protection level and period. The ultimate goal of this work is Production of inactivated Rift valley fever vaccine in the lyophilized form to decrease the time and efforts consumed during vaccine preparation as well as minimization of the economic efficacy of the vaccine production process.

\section{MATERIALS AND METHODS}

\section{Materials}

\section{Experimental animals}

\section{Unweaned baby mice}

Ten, three to four days old baby mice were supplied by Breeding Unit, Veterinary Serum and Vaccine Research Institute (VSVRI), Abbasia, Cairo, were used for detection of virus inactivation completion, each mice was inoculated $\mathrm{I} / \mathrm{C}$ with $0.1 \mathrm{ml}$ inactivated RVF virus which was supplied RVF Department, (VSVRI). Abbasia, Cairo

\section{Adult mice}

Sixty Swiss albino weaned mice and specific pathogen-free, 21-30 days old were supplied by the Breeding Unit, (VSVRI) and it was used in $\mathrm{ED}_{50}$ potency test. Fifty mice (10 for each dilution) for vaccine dilutions and ten kept as control.

\section{Newly born lamb}

Five apparently healthy newly born lambs (7-10 days old) were used for safety tests of prepared freezedried inactivated RVF Vaccine; it was supplied by Breeding Unit, (VSRI).

Sheep

Healthy fifteen adult local breed sheep of 3-4 month old were used for evaluation of their immune response to the prepared vaccine (potency test). All of these animals were screened using SNT and proved to be free from RVF antibodies. They were housed under strict hygienic measures in insect-proof stables receiving balanced ration and adequate water.

RVFV (ZH 501): The original virus was obtained from RVF Department, (VSVRI). It was used for the preparation of lyophilized Rift valley fever vaccine, $\mathrm{SNT}$, and $\mathrm{ED}_{50}$.

Tissue Culture (Vero Cells): The cells were grown and maintained according to Macpherson and Stocker, (1962) it was used for virus propagation, titration, vaccine preparation, and serum neutralization test. It was obtained from RVF Department, Veterinary Serum And Vaccine Research Institute (VSVRI).

\section{Reagents}

Binary Ethyleneimine (BEI): $\quad 0.1 \mathrm{M}$ Binary Ethyleneimine (BEI) stock solution prepared from 2bromoethylamine hydrobromide (Aldrich Chemical Co., LTD) and 0.2 N NaOH, according to Bahnemann
(1990) and Mark (2004) It was used for Rift valley fever virus inactivation process.

Saponin: was obtained from ACROS co. (New Jersey, USA). And used as vaccine diluents, adjuvant for lyophilized vaccines. The concentration of the saponin $1 \mathrm{mg} /$ dose or (ml vaccine) was added according to Samuilenko (1982) and Nehal et al., (2017)

Stabilizer: It was prepared to contain 2.5\% lactalbumin hydrolysate and 5\% sucrose OIE (2018).

Aluminum hydroxide inactivated RVF vaccine: Tissue culture inactivated Rift Valley Fever vaccine was supplied by RVF Department at VSVRI.

\section{Methods}

Virus titration and inactivation RVF virus was propagated and titrated in Vero cells according to ElNimr, (1980) and Taha, (1982) and inactivated by Binary Ethyleneimine (BEI) according to Bahnemann (1990) and Mark (2004)

Validation of virus inactivation completion Samples from the inactivated virus was checked for the presence of the active virus, in Tissue culture according to OIE (2012) and in baby mice according to El Nimr (1980) and Eman (1995)

Preparation of Lyophilized RVF vaccine a master seed RVFV (ZH501) was propagated on Vero cells for an additional three passages to prepare vaccine working virus. From the vaccine seed virus, a vaccine stock viral fluid was prepared by carrying another one passage on Vero cells and the bulk virus harvest fluid was kept at $-70{ }^{\circ} \mathrm{C}$ till titration and sterility tests were done. Vaccine stock viral fluid having virus titer should not less than $8 \log _{10} \mathrm{TCID}_{50} / \mathrm{ml}$ Mayer et al., (1978). Vaccine stock viral fluid was inactivated by $0.001 \mathrm{M}$ BEI at $37^{\circ} \mathrm{C}$ for 24 hours Nehal, (2006). The inactivated virus was mixed with an equal volume of stabilizer then distributed in vials $(2 \mathrm{ml} / \mathrm{vial})$ and subjected for freeze-drying.This vaccine formula reconstituted in saponin $(1 \mathrm{mg} / \mathrm{dose})$ as an adjuvant at the time of inoculation.

\section{Vaccine Quality Control}

Sterility Test: Samples were taken from the final product as well as the virus fluid before inactivation process and tested on Nutrient agar medium, Sabouraud dextrose agar medium, Thioglycolate medium (Oxford, England) and PPLO (broth) medium for detection of bacterial fungal and mycoplasma contaminations (Code of Federal Regulations, (2005) and OIE, (2015).

Safety Test : Three lambs were inoculated with $10 \mathrm{ml}$ of prepared lyophilized vaccine (five $\mathrm{ml} \mathrm{S} / \mathrm{C}$ and five $\mathrm{ml} \mathrm{I} / \mathrm{P}$ ), while two were kept as control. Lambs were observed daily to two weeks for any rise of temperature, death, and any abnormal clinical signs post-vaccination. 
Potency test to prepared lyophilized RVF vaccine $\left(\mathbf{E D}_{\mathbf{5 0}}\right)$ :

In adult mice: It was applied according to Randall $\boldsymbol{e t}$ al., (1964). Fivefold dilutions of the prepared RVF vaccine were diluted from 1:1 to 1:625. Ten mice for each dilution each mice was inoculated with $0.2 \mathrm{ml} / \mathrm{I} / \mathrm{P}$ as the first dose followed by booster dose one-week interval, all inoculated mice were challenged with $0.1 \mathrm{ml}$ of RVFV containing $10^{3}-10^{4}$ MIPLD $_{50} / \mathrm{ml}$, Mice were kept under observation for 21 days where deaths were recorded daily and $\mathrm{ED}_{50} / \mathrm{ml}$ was calculated according to Reed and Muench (1938).

In sheep: Fifteen sheep were divided into three groups (five sheep/group). Each group was inoculated with two doses, one for vaccination then second for bolstering. The groups were divided as follow:

\begin{tabular}{|cccc|}
\hline Gp No. & GP 1 & Gp 2 & Gp 3 \\
\hline $\begin{array}{c}\text { Type } \\
\text { of } \\
\text { vaccine }\end{array}$ & $\begin{array}{c}\text { Lyophilized } \\
\text { RVF } \\
\text { vaccine }\end{array}$ & $\begin{array}{c}\text { ALOH } \\
\text { gel } \\
\text { inactivated } \\
\text { RVF } \\
\text { vaccine }\end{array}$ & $\begin{array}{c}\text { Non } \\
\text { vaccinated } \\
\text { (was kept } \\
\text { as control } \\
\text { negative) }\end{array}$ \\
\hline Dose & $1 \mathrm{ml}$ & $1 \mathrm{ml}$ & $1 \mathrm{ml}$ \\
\hline Rout & $\mathrm{S} / \mathrm{C}$ & $\mathrm{S} / \mathrm{C}$ & $\mathrm{S} / \mathrm{C}$ \\
\hline
\end{tabular}

Samples were collected in sterile dry clean screw-capped bottles, then left at room temperature for 1-2 hours then placed in the refrigerator overnight, and then the serum was centrifuged at $3000 \mathrm{rpm}$ for 10 minutes, then kept at $-20^{\circ} \mathrm{C}$ until used for antibody detection by SNT and ELISA

Collection of samples: The blood samples were collected at weekly intervals, then monthly till the end of the experiment period post-vaccination for serological tests (SNT, ELISA).

For the Evaluation of the humoral immune response, blood samples were collected from vaccinated and non vaccinated sheep were tested 12 months for the presence of antibody against RVF virus by SNT according to the method of constant serumvirus dilution procedure. The serum-neutralizing index was calculated according to Reed and Muench (1938) and indirect ELISA according to Voller (1976).

\section{RESULTS}

\section{Propagation of RVF virus (ZH501) in cell culture:}

The virus was produced under Biosafety measures; it was propagated in Vero cells for three successive times to increase the virus yield. a prominent CPE of RVF virus in Vero cells appeared as rounding and aggregation in clusters (grapes like aggregation). As shown in Photo (1, 2), Titer was $10^{8}$ $\log _{10} \mathrm{TCID}_{50} / \mathrm{ml}$.

Photo 1: Normal Vero cells

Photo 2: CPE of RVFV on Vero cells
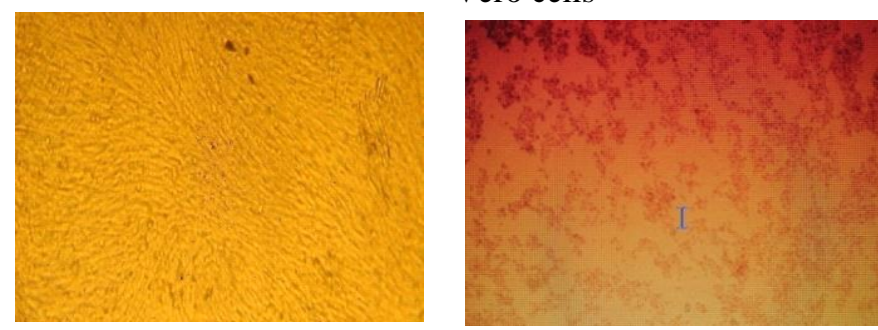

Titration of RVF virus ZH501 in cell cultures: The virus titer was increased gradually in the first passage from $10^{7.5}$ to $10^{7.7} \mathrm{TCID}_{50} / \mathrm{ml}$ in the second passage till reaching an output at the 3rd passage of $10^{8} \mathrm{TCID}_{50} /$ $\mathrm{ml}$. The harvested virus of the $3^{\text {rd }}$ passage was used for vaccine production.

Validation of virus inactivation completion: in baby mice and in tissue culture inactivated RVF virus was safe when they were inoculated in mice as no mortalities or any signs of illness were observed on inoculated mice during the test (10 days) in baby mice. And no CPE or any effect on Vero Cells was observed.

Table 1: Results of safety test in Vero cells and baby mice

\begin{tabular}{|cccc|}
\hline \multirow{2}{*}{ Type of virus } & \multirow{2}{*}{$\begin{array}{c}\text { Vero } \\
\text { cells }\end{array}$} & \multicolumn{2}{c|}{ Baby mice I/C } \\
\cline { 3 - 4 } & Dead & Alive \\
\hline $\begin{array}{c}\text { BEI inactivated } \\
\text { RVF virus }\end{array}$ & No CPE & $0 / 10$ & $10 / 10$ \\
\hline
\end{tabular}

CPE: cytopathic effect.

\section{Quality Control of prepared vaccine}

Sterility: The prepared vaccine gave satisfactory results. It was free from mycoplasma, aerobic, anaerobic bacteria and fungi.

Safety test: No rise in body temperature with no postvaccinal reaction and any abnormal signs.

Potency test of the prepared vaccine in mice (ED50): The lyophilized inactivated RVF vaccines gave $0.0010 \mathbf{E D}_{50} / \mathrm{ML}$ while the Aluminium hydroxide gel inactivated RVF vaccine gave $\mathbf{0 . 0 0 1 9} \mathbf{E D}_{\mathbf{5 0}} / \mathbf{M L}$ (permissible limit less than $0.02 / \mathrm{ml}$ ).

The humoral immune response of vaccinated sheep using serum neutralization test (SNT) and ELISA was shown in tables (3-4) and figure (1-2). 


\section{Efficacy Of Freeze-Dried Inactivated}

Table 2: Mean of neutralizing indices of sheep vaccinated with aluminum hydroxide and lyophilized inactivated RVF vaccine:

\begin{tabular}{cccc}
$\begin{array}{c}\text { Time of Sampling } \\
\text { (weeks post- } \\
\text { vaccination) }\end{array}$ & Group 1 & Group 2 & Group 3 \\
\cline { 2 - 4 } & 0.39 & 0.35 & 0.23 \\
\hline Pre & 1.3 & 0.93 & 0.23 \\
\hline 1 & 2.1 & 1.7 & 0.45 \\
\hline 2 & 3.28 & 3.13 & 0.34 \\
\hline \multicolumn{4}{c}{ Booster dose } \\
\hline 4 & 3.25 & 3.02 & 0.36 \\
\hline 8 & 3.22 & 3.01 & 0.51 \\
\hline 12 & 3.08 & 2.74 & 0.6 \\
\hline 16 & 2.88 & 2.67 & 0.46 \\
\hline 20 & 2.72 & 2.67 & 0.23 \\
\hline 24 & 2.62 & 2.56 & 0.23 \\
\hline 28 & 2.30 & 2.08 & 0.23 \\
\hline 32 & 2.1 & 1.92 & 0.47 \\
\hline 36 & 1.8 & 1.73 & 0.45 \\
\hline 40 & 1.24 & 1.17 & 0.23 \\
\hline 44 & 0.92 & 0.64 & 0.47 \\
\hline 48 & & &
\end{tabular}

Group 1: inoculated with prepared RVF vaccine adjuvanted with saponin the time of inoculation. Group 2: inoculated with ALOH inactivated RVF vaccine.

Group 3: control negative.

Protective index $=1.5$

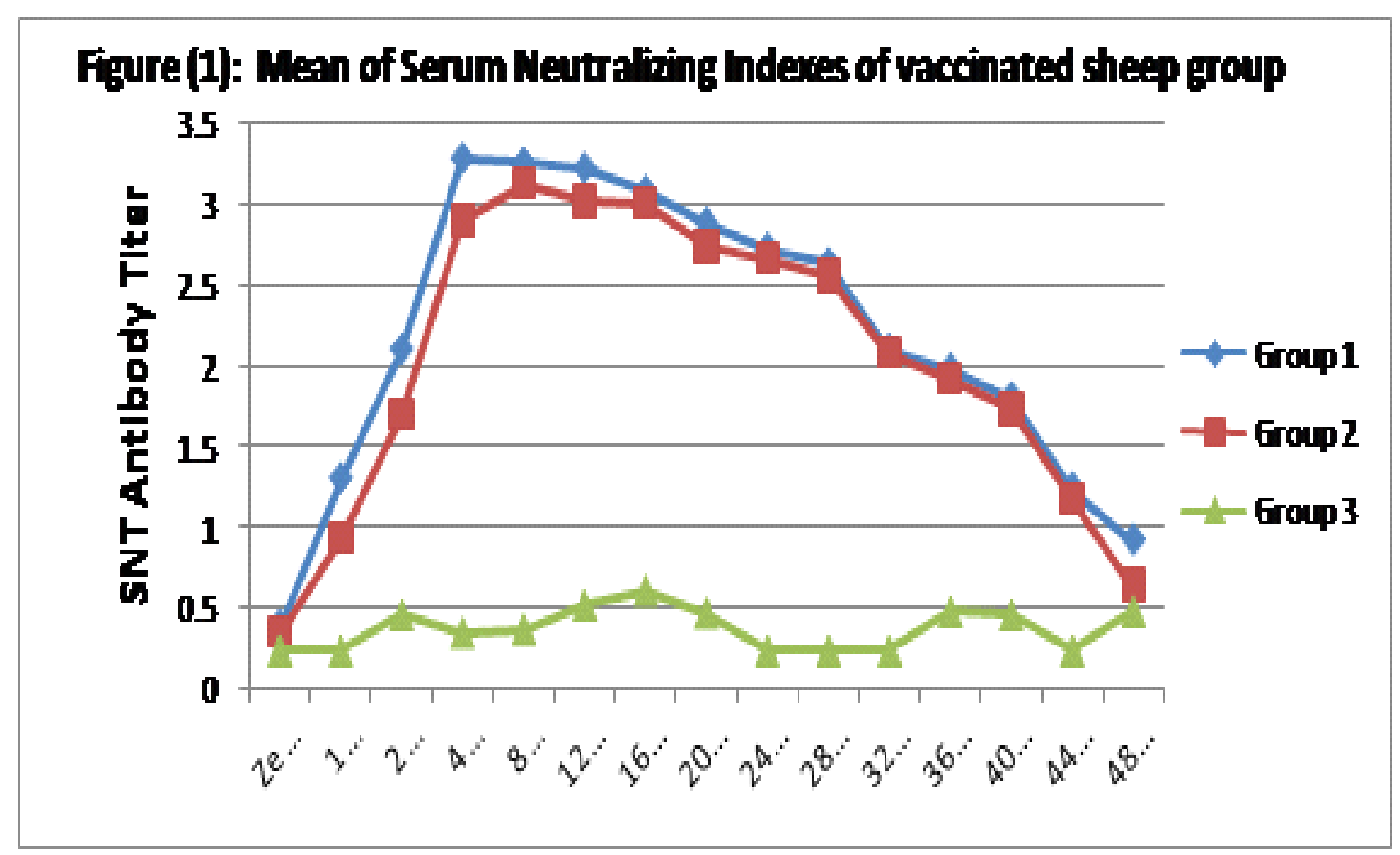




\section{Atwa, M.H et al.}

Table 3: Mean values of ELISA optical density in sheep vaccinated with different vaccinated sheep groups

\begin{tabular}{cccc}
\hline & \multicolumn{2}{c}{ Mean optical densities at different period post-vaccination } \\
Time of Sampling & & & \\
(weeks post-vaccination) & & & Group 2 3 \\
& Group 1 & 0.013 & 0.01 \\
\hline Pre & 0.019 & 0.14 & 0.16 \\
\hline 1 & 0.19 & 0.277 & 0.01 \\
\hline 2 & 0.286 & 0.312 & 0.012 \\
\hline & & Booster dose & 0.014 \\
\hline 4 & 0.343 & 0.287 & 0.01 \\
\hline 8 & 0.332 & 0.283 & 0.01 \\
\hline 12 & 0.312 & 0.275 & 0.013 \\
\hline 16 & 0.298 & 0.263 & 0.015 \\
\hline 20 & 0.289 & 0.258 & 0.011 \\
\hline 24 & 0.279 & 0.243 & 0.012 \\
\hline 28 & 0.268 & 0.238 & 0.011 \\
\hline 32 & 0.257 & 0.234 & 0.012 \\
\hline 36 & 0.249 & 0.228 & 0.016 \\
\hline 40 & 0.241 & 0.187 & 0.01 \\
\hline 44 & 0.206 & 0.176 &
\end{tabular}

Group 1: inoculated with prepared lyophilized RVF vaccine adjuvanted with saponine at the time of inoculation.

Group 2: inoculated with ALOH inactivated RVF vaccine,

Group 3: control negative.

Positive titer $($ Cut Off $)=0.224$

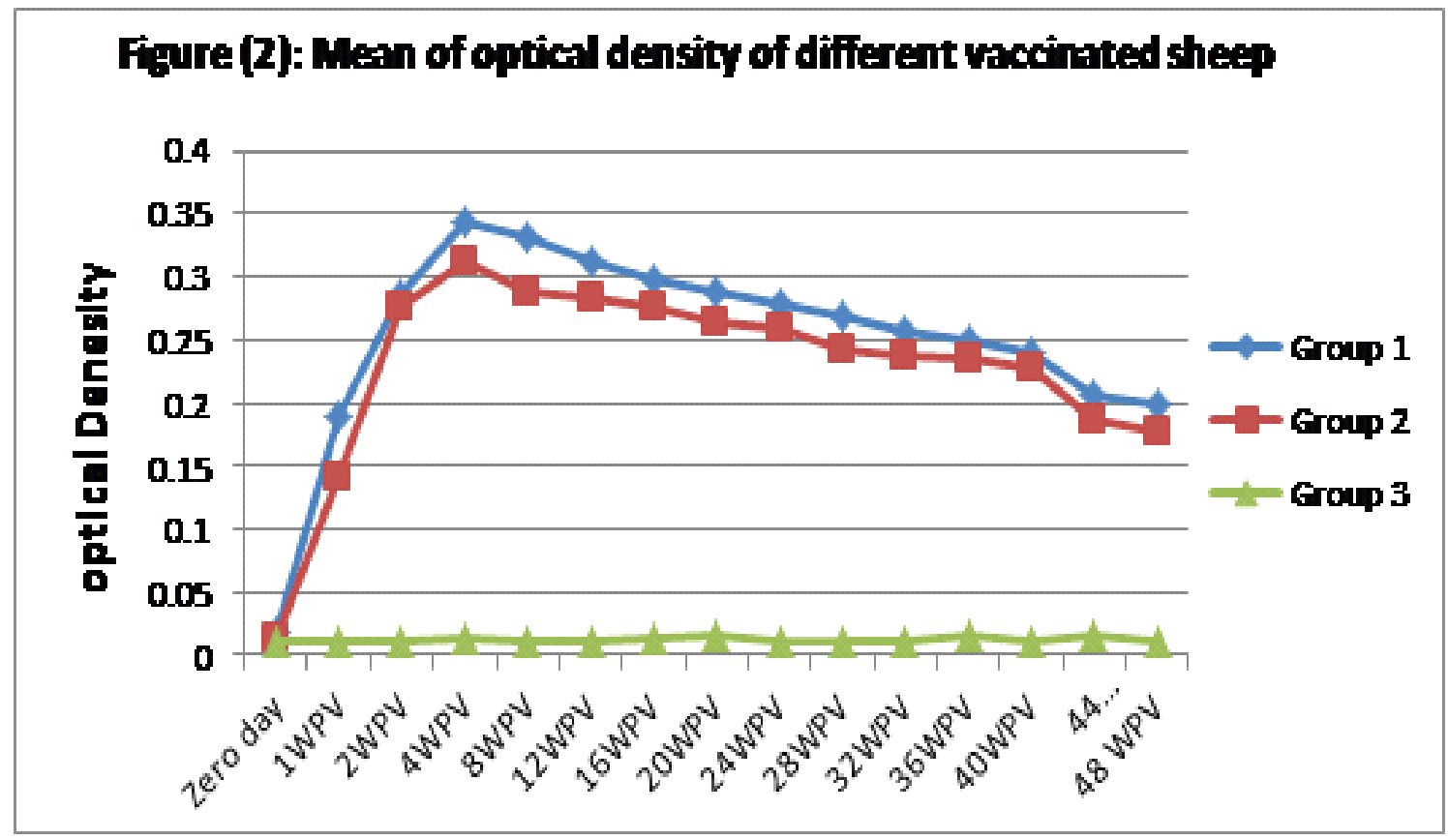




\section{Efficacy Of Freeze-D DISCUSSION}

The progress in vaccine production is directed towards the selection of the proper adjuvant that can elaborate high and long-standing immunity (Alsaid $\boldsymbol{e} t$ al.,2020), but using a large number of adjuvants during vaccine production will increase the vaccine's cost. So this study aimed to produce a new type of inactivated RVF vaccine using the process of lyophilization which enhances the stability and thus the marketability of a product. This study was designed to prepare Lyophilized RVF vaccine inactivated with BEI and reconstituted at the time of inoculation in saponin $(1 \mathrm{mg} /$ dose $)$ as an adjuvant and compare its efficacy with the efficacy of aluminum hydroxide inactivated RVF vaccine.

Concerning the RVF virus was titrated using the infectivity method according to Reed and Muench, (1938) using the Vero cell line. The titer of the virus was $10^{8} \mathrm{TCID}_{50} / \mathrm{ml}$. CPE on the Vero cell appeared rounded and aggregated in clusters as shown in photo (1). By detecting the validation of virus inactivation completion in mice and tissue culture, we found a satisfactory results for 14 days postvaccination with no clinical abnormalities or deaths. The prepared lyophilized RVF vaccine was proven to be sterile and free from mycoplasma, aerobic, anaerobic bacteria and fungal contamination, These results agreed with Wassel et al., (1996) and Code of Federal Regulations, (2005), reported that the final product should be free from mycoplasma, bacteria, and fungi.

The prepared vaccine was safe in lambs as there is no rise in body temperature which remained within the normal range for 14 days post-vaccination with no clinical abnormalities or deaths. The prepared lyophilized inactivated RVF vaccine gave 0.0010 $\mathrm{ED}_{50} / \mathrm{ml}$ in mice and this agreed with Randall $\boldsymbol{e t}$ al., (1964); Maha et al., (2017) who used $\mathrm{ED}_{50}$ test in the evaluation and detect potency of inactivated vaccine which are less than $0.02 / \mathrm{ml}$ in mice as recommended by WHO (1983)

Immunization in sheep vaccinated with aluminum hydroxide inactivated RVF vaccine gave protective titer at second-week post-vaccination (1.7) then reach to peak at $4^{\text {th }}$ week $(3.13)$ then began to decline till ten months (1.73) as illustrated at the table (2) and figure (1), this agrees with El Karamany (1981) who found the neutralizing antibodies in sheep and goats vaccinated with formaldehyde inactivated RVF vaccine could be detected seven days postvaccination and reached a level of 3.7 at 40 days postvaccination. The neutralizing antibody reaches to the peak (2.7) at 12 weeks post-vaccination and continues in protective level till 28 weeks post-vaccination, these results agree with that obtained by Gihan and Elian, (1997) who found the protective antibody level of sheep vaccinated with inactivated vaccine till seven months. These results also agreed with that obtained by Abdel Samea et al., (1994) who explained that sheep vaccinated with inactivated RVF vaccine had a protective antibody titre till seventh month the postvaccination. While the prepared lyophilized RVF vaccine gave protective titre at second-week postvaccination (2.1), then reach to peak at $4^{\text {th }}$ week (3.28) then began to decline till the end of tenth-month postvaccination (1.8), these results backed to using of saponin as adjuvant as shown in table (3) and this agrees with Oda et. $\boldsymbol{a l}$., (2000) who reported that Saponin based adjuvants can modulate the cellmediated immune system as well as to enhance antibody production and have the advantage that only a low dose is needed for adjuvant activity. The ELISA results come in parallel to results obtained by SNT (Coenraad et al., 1998) .

\section{CONCLUSION}

From these studies, It can be concluded that, the lyophilized inactivated RVF vaccine is highly immunogenic and economic than the ALOH inactivated RVF vaccine so we recommended using lyophilized inactivated RVF vaccine in the field.

\section{REFERENCES}

ABDEL GHAFFAR, S., MOHSEN, A., AYOUB, N.; ELNIMR, M. AND FATHIA, M. 1979. Rift Valley fever in Egypt III. Diagnosis and vaccination.14th Arab. Vet. Cong., 24-29 march Cairo, page 1-11.

ABDEL-SAMEA, M. M.; ELIAN, K. AND, GIHAN, K. M. 1994. the effect of Rift Valley Fever and Sheep Pox vaccines on the immune response of sheep. J. Egypt. Vet. Med. Ass. No.2:129-136 (1994).

ALSAID , S. A., ABUl MAGD, D. M., ATWA, M. H., SOLIMAN, S. M. 2020. Evaluation of the cellular and humoral immune response of sheep vaccinated with inactivated Rift Valley Fever Vaccine Adjuvanted with Montanide gel $01^{\mathrm{TM}}$. Journal of Applied Veterinary Sciences, vol.5(1):22-34.

BAHNEMANN, H.G. 1990. Inactivation of viral antigens for vaccine preparation with particular reference to the application of binary ethyleneimine vaccine, 8: 299-303.

CENTRAL DISEASE CONTROL AND PREVENTION CDC. 2007. Ministry of Livestock and Fisheries, Rift Valley Fever information.

CENTERS DISEASE CONTROL AND PREVENTION (CDC). 2015. Rift Valley Fever.

CODE OF FEDERAL REGULATION. 2005. Animal and animal products 9, Published by the Office of the Federal Register National Archives and administration. Vet Microbial, 16(2): 101-107.

COENRAAD H., JEAN-MARC S., ARNOUD A., MICHAEL B.; LUKAS B., KLAUS C., ARNOLD DAAS, JOHAN DESCAMPS, ROLAND D., JULIA F., 
MARLIES H., MARGOT VAN DER K., ROGER L.,EHAL, S. SALEH. 2006. Preliminary trials for the JULIE M., DOROTHEA S., DONALD S. AND production of equine viral abortion inactivated vaccine. ANTONIO V. 1998. Validation Alternative Methods for the Ph. D. Thesis, Virology Benha Univ.

Potency Testing f Vaccines. The Report and RecommendationNEHAL S.SALEH, EMAN M.EBEID, FATMA F. WARDA, of ECVAM Workshop 31. ATLA, 26: 747.

EL-GABRY, G.H.; NAWAL, M.A.; HADIA A.; FATHIA, M.M. AND AYOUB, N. N. 1994. Unclassical picture of Rift valley Fever in man and animals in Aswan Governorate . Vet. Med. J; Giza. 42 (1): 135-138.

EL KARAMANY, R. M. 1981. Studies on the production of Rift Vally Fever vaccine in tissue culture. Ph. D. Thesis (Microbiology), Fac. Vet. Med., Cairo Univ.

EL-NIMR, M. M. 1980. Studies on the inactivated vaccine against Rift Valley Fever.Ph. D. Thesis (Microbiology) Fac. Vet. Assuit. Univ. Egypt

EMAN, M. S. 1995. Studies on Rift Valley Fever vaccine inactivated with Binary Ph. D. Thesis, Microbiology, Fac. of Vet. Med, Cairo Univ.

FABURAY. B.; LABEAUD, A.D.; MCVEY, D.S. AND WILLIAM, C. W. 2017. The involving transmission pattern of Rift Valley Fever in the Arabian Peninsula. amany Acad. Sci. 969: 201- 204.

FAO. 2003. Rift Valley Fever. EMPRES Transboundary Animal Disease. Bulletin, issue No. 23.

GIHAN, K. M.; ELIAN, K. A. 1997. Comparative studies on the serological response of locally produced live attenuated and inactivated Rift Valley vaccines. Egypt. Vet. Med. Ass., 57, No. 1: 949 - 957.

IMAM, I. Z. E.; M.A.; DARWISH, M.A. AND ELKARAMANY J. R. 1979. an epidemic of Rift Valley fever in Egypt. Diagnosis Rift Valley fever in man. Bulletin of the World Health Organization. 57(3); 437.

KATHRYN, A.; HUBBARD, B. S. C.; ARTHUR BUSKERVILLE, DVSC, PH D. AND JOHN. 1991. The ability of a mutagenized virus variant to protect young lambs from Rift Valley Fever.Amer. J. Vet. Res., Vol.52: Jan , 1991.

MACPHERSON, J.A. AND STOCKER, N.G. 1962. Polyoma Transformation of hamster cell clones an investigation of hamster cell clones of genetic factors affecting all competence. Virology, 16: 147.

MAHA G. SOLIMAN1, ALY F. MOHAMED, RASHA A. EL SAYED1 AND ASMAA A. ABO ELQASEM. 2017. The immune-enhancing potential of the sphere and rod gold nanoparticles to Rift Valley Fever vaccine relative to time: in vitro study. ejbps, v.4: 529.

MARK, W. MELLENCAMP. 2004. Chemically inactivated EHV-1 kya virus; and an adjuvant which includes crosslinked olefinically unsaturated carboxylic acid polymer. Patents, publication number US 6803041 B2.

MAYR A., THEIN, P. \&SCHEID, N. 1978. Immunization experiments with inactivated EHV-1. In proceeding 4thInt. Conf., Equine infect. Dis., Lyon edited by Bryans, J.T.and Gerber Vet. Pub.Inc. princtone, New Jersey, 57 .

NDEYE, S. B.; HAMPATE, B.; GAMOU F.; ELKHALIL, I.; MAMADOU, Y.; DIALLO, ABDOURAHMANE, S.; PAPE, M. S.; OUSMANE, F.; BRAHIME, MOHAMED L. S.; AND AMADOU, A. S. 2015. Detection of the Northeastern African Rift Valley Fever Virus Lineage during the 2015 Outbreak Mauritania Open Forum Infectious Diseases. 102 ASHRAF T. ELDAKHLY, NASHWA K. MADKOUR, MAHMOUD A, ELKABANY AND IBRAHEM M. A. SOLIMAN. 2017. Lyophilized EHV-1 vaccine inactivated and adjuvanted by quillaja Saponaria Molina extract. J. of Virol. Sci., Vol.1:123.

NGUKU P.M.1.; SHARIF, SK.; MUTONGA, D.; AMWAYI, S; OMOLO .J.; MOHAMMED, O.; FARNON, E.C.; GOULD.; L..H; LEDERMAN, E.; RAO, C, SANG R, SCHNABEL D, FEIKIN DR, HIGHTOWER A, NJENGA M.K.; BREIMAN, R.F. 2006. An investigation of a major outbreak of Rift Valley fever in Kenya: The American journal of tropical medicine and hygiene. 5; 83(2): 05-13.

ODA K, MATSUDA H, MURAKAMI T, KATAYAMA S, OHGITANI T, YOSHIKAWA M. 2000. Adjuvant and hemolytic activities of 47 saponins derived from medicinal and food plants. BiolChem 381:67-74.

OIE TERRESTRIAL MANUAL. 2012. RVF Chapter 2.1.15. - pp (334-343).

OIE. 2018. OIE Terrestrial manual 2018, chapter 2.1.14.

OIE TERRESTRIAL MANUAL. 2015. Rift Valley Fever, May Chapter 2.5.9.pp.1-12.

RANDALL, R.; BINN, L.N. AND HARRISON, V.R. 1964. Immunization against Rift Valley Fever. Studies on the immunogenicity of the lyophilized formalininactivated vaccine. J. Imm., 93(2): 293-299.

REED, L.J., AND MUENCH, H. 1938. A simple method for estimating 50 percent endpoint. Amer.J. Hyg.,27: 493.

SAMIA, A. K. 2011. Observations on rift valley fever virus and vaccines in Egypt. Virol J. 2011; 8: 532.

SAMUILENKO, A.Y.A. 1982. Dependence of immunity on the dose of adjuvant (with Saponin in FMD vaccine). Veterinary, Moscow, USSR, No. 9, 28-29, blokanbinant, shehelkov, Moskovskaya Oblast, USSR.

SELLERS, R.F.; PEDGLEY, D.E., AND TUCKER, M.R. 1982. RiftValley fever, Egypt 1977, disease spread by windborne insect vectors.

TAHA, M. M. 1982. Studies on the inactivated vaccine of Rift Valley Fever Virus.Ph. D. Thesis (Microbiology), Fac. Vet. Med., Cairo Univ.

VOLLER, A.; BIDWELL, D. AND BARTLETT, A. 1976. Microplate enzyme immunoassay for the immunediagnosis of virus infection .Am. Soc. for Micro.,506.

WASSEL, M.S.; ABOULSAOUD, S.; GIRGIS, S.; HUSSEIN, A.Z. AND EMAN, EL-RAWY. 1996. Trials for preparation and evaluation of a combined vaccine for IBR (IBR-V),(BVD-V), (PI-3V), P. multocida and P. haemolytica in Egypt, Assiut Vet.Med. J., 35 (70).

WHO/FAO MEETING. 1983. The use of veterinary vaccines for prevention and control of Rift Valley fever. Bulletin of the World Health Organization, 61 (2): 261.

How to cite this article:

Atwa, M.H , Maha Raafat Abd El-Fadeel, Heba A. Khafagy, Alaa A.El-Kholy, Ebtsam E.Z.Kotb, and Marwa, F.Mahmoud. 2020. Efficacy Of Freeze-Dried Inactivated Rift Valley Fever Vaccine. Journal of Applied Veterinary Sciences, 5(2):33-39.

DOI:

HTTPS://DX.DOI.ORG/10.21608/JAVS.2020.85571 